Al-Tanzim : Jurnal Manajemen Pendidikan Islam

E-ISSN: 2549-5720 P-ISSN: 2549-3663

Vol. 03 No. 02 (2019) : 73-84

https:// ejoumal.unija.ac.id/ index.php/al-tanzim

\title{
KEPEMIMPINAN TRANSFORMASIONAL KYAI PADA LEMBAGA PENDIDIKAN ISLAM
}

\author{
Bashori \\ Universitas Islam Negeri Imam Bonjol, Padang, Indonesia \\ Email :bashori@uinib.ac.id
}

\begin{tabular}{|c|c|c|}
\hline \multicolumn{3}{|c|}{ DOI: http://doi.org/10.33650/al-tanzim.v3i2.535 } \\
\hline Received: Juli 2019 & Revised: November 2019 & Approved: November 2019 \\
\hline
\end{tabular}

\begin{abstract}
:
This research presents about Kyai's transformational leadership in managing Islamic educational institutions in order to have strong excellence and competitiveness, in the midst of competition between educational institutions. The study of Kyai's leadership has its own uniqueness, considering that Kyai is a charismatic figure and has a high spirituality value for a community of people, who must play a dual role as a leader and also a manager in the educational institution he leads, namely pesantren. This research uses a qualitative approach to with library research. The data analysis technique uses content analysis. The results showed that; Kyai as a transformative leader in managing his educational institutions, especially pesantren has four dimensions; First, charismatic leadership, where Kyai's position is used as a role model by his followers, secondly inspirational motivation, where a Kyai is able to inspire and motivate followers to achieve the goals of pesantren, third, intellectual stimulation which is able to foster ideas and ideas from others to advance pesantren educational institutions, fourth, individualized consideration, in which a Kyai wants to listen to the aspirations and input of others for the development of the educational organization he leads.
\end{abstract}

Key words : Transformational Leadership, Kyai, Islamic Education Institution

\begin{abstract}
Abstrak
Penelitian ini menyajikan tentang kepemimpinan tranformasional Kyai dalam mengelola lembaga pendidikan Islam agar supaya memiliki keunggulan dan daya saing yang kuat, di tengah persaingan antara institusi pendidikan. Kajian tentang kepemimpinan Kyai memiliki keunikan sendiri, mengingat Kyai merupakan sosok yang kharismatik dan memiliki nilai spiritualitas tinggi bagi suatu komunitas masyarakat, yang harus memerankan peran ganda sebagai leader dan juga manager pada lembaga pendidikan yang dipimpinnya, yaitu pondok pesantren. Penelitian ini menggunakan pendekatan kualitatif jenis library research. Tekhnik analisis datanya menggunakan analisis isi. Hasil penelitian menunjukkan bahwa; Kyai sebagai pemimpin yang transformatif dalam mengelola lembaga pendidikannya, khususnya pondok pesantren memiliki empat dimensi; Pertama, kepemimpinan kharismatik, di mana posisi Kyai dijadikan sebagai panutan oleh pengikutnya, kedua inspirational motivation, di mana seorang Kyai mampu menginsiprasi dan memberi motivasi bagi pengikutnya untuk mencapai tujuan pesantren, ketiga, intellectual stimulation yang mampu menumbuhkembangkan ide dan gagasan dari orang lain untuk memajukan lembaga pendidikan pesantren, keempat, individualized consideration, di mana seorang Kyai mau mendengarkan aspirasi dan masukan-masukan orang lain untuk pengembangan organisasi pendidikan yang dipimpinnya.
\end{abstract}

Kata Kunci : Kepemimpinan Transformasional, Kyai, Lembaga Pendidikan Islam 


\section{PENDAHULUAN}

Persoalan kepemimpinan menjadi menarik untuk selalu dikaji dalam setiap momen organisasi (Grisham, 2006), karena menyangkut pentingnya pengetahuan tentang konsep kepemimpinan dalam konsep Islam, terutama kepemimpinan lembaga pendidikan Islam. Kepemimpinan dalam dunia pendidikan bertujuan untuk menentukan arah suatu kelompok, sehingga tercapainya sebuah tujuan bersama yang telah ditentukan dan disepakati bersama. Kepemimpinan dalam hal ini dipahami sebagai suatu aktivitas dalam kegiatan organisasi yang menggunakan wewenang, pengaruh, dan kekuasaannya untuk mempengaruhi orang lain dalam aktivitas kependidikan yang dipimpinnya guna mencapai tujuan yang telah disepakati bersama (Syam, 2017).

Kepemimpinan yang ditunjukkan oleh seorang pemimpin sangat mempengaruhi terhadap arah dan kebijakan dari system kepemimpinannya. (Guthrie \& Ph, 2010). Pemimpin pendidikan Islam yang memiliki kemampuan mempengaruhi seluruh elemen yang ada dalam sebuah lembaga, akan lebih mudah mengarahkan dan memanage anggota organisasinya ke arah tujuan yang ingin dicapai, karena pemimpin merupakan lokomotif dan motor penggerak bagi utama perbaikan hidup manusia dan organisasi.

Dalam konteks keorganisasian, perlombaan untuk menjadi yang terbaik, terdepan, unggul merupakan fitrah manusia. Begitu juga dalam lembaga pendidikan Islam, di mana persaingannya bukan hanya dengan sekolah yang nota benenya sekolah umu, akan tetapi persaingannya dengan sesama lembaga pendidikan Islam yang ada. Sehingga masing-masing lembaga pendidikan dituntut untuk melakukan inovasi dalam memenangkan persaingan tersebut.

Dalam konteks ini, kepemimpinan memegang peranan penting untuk memajukan organisasi. Salah satu kepemimpinan yang sesuai dalam hal ini adalah kepemimpinan transformasional. Peningkatan kualitas lembaga pendidikan Islam harus dibarengi dengan tekat perubahan yang lebih baik. Dia tidak hanya berhenti pada tatanan rutinitas, akan tetapi perilaku inovasi terhadap kualitas lembaga pendidikan Islam (Syam, 2017). Sementara itu, Afandi (2013) mengungkapkan bahwa fungsi kepemimpinan dalam pendidikan terletak pada dua aspek kemampuan, yaitu kemampuan manajerial (managerial) dan pemeliharaan (maintenance).

Selain itu, Syahrul (2015) mengungkapkan bahwa kepemimpinan menjadi faktor penting dalam menghadapi perubahan keorganisasian, melakukan respon terhadap krisis dan menggunakan semua pontensi organisasi dalam rangka pertumbuhan (growth) dan tercapainya tujuan organisasi, keyakinan yang kuat tentang cita-cita bersama, dan sinergi semua komponen di dalamnya. 
Al-Tanzim : Jurnal Manajemen Pendidikan Islam E-ISSN: 2549-5720 P-ISSN: 2549-3663

Vol. 03 No. 02 (2019) : 73-84

Dalam hal ini, pemimpin transformasional merupakan pemimpin yang memberikan inspirasi bagi para pengikutnya untuk mengesampingkan kepentingan pribadi demi kepentingan umum dan kebaikan serta kemajuan organisasi. Mereka memiliki kemampuan dan pengaruh yang kuat dari para pengikutnya (Widayati \& Rahardjo, 2017).

Kepemimpinan transformasional dalam hal ini diilustrasikan dengan suatu gaya atau model kepemimpinan yang dapat membangkitkan atau memotivasi anggota pada organisasinya, sehingga dapat mencapai kinerja yang optimal dan melebihi dari apa yang diperkirakan sebelumnya.

Berdasarkan penelitian yang telah dilakukan oleh para peneliti sebelumnya tentang kepemimpinan tranformasional, Suyatminah (2013) menyatakan bahwa ada pengaruh yang signifikan antara kepemimpinan transformasiomal dan kedisiplinan kerja guru TK PNS Se-Kecamatan Bantul. Murtiningsih (2015) menyatakan bahwa kepemimpinan transformasional memiliki pengaruh signifikan terhadap kinerja organisasi. kepemimpinan transformasional memberikan pengaruh yang cukup signifikan terhadap kinerja organisasi. Sedangkan variabel kepercayaan dan variabel kepuasan kerja, memiliki peran sebagai variabel mediasi. Begitu juga Senny et al (2018), menyatakan bahwa gaya kepemimpinan transformasional dalam manajemen PAUD Kecamatan Sidorejo memberikan motivasi inspiratif dan stimulasi intelektual kepada bawahannya sehingga tugas yang diberikan dapat dicapai secara maksimal.

Dari paparan yang telah diuraikan di atas, penulis mencoba membahas lebih jauh tentang kepemimpinan tranformasional Kyai pada lembaga pendidikan Islam, mengingat Kyai adalah sosok yang memiliki keunikan sendiri dan memiliki nilai-nilai transenden pada masyarakatnya. Dengan demikian, kajian ini ini akan membawa khazanah keilmuan baru tentang kepemimpinan pendidikan Islam dari sudut pandang kepemimpinan Islam secara komprehenshif; yaitu pemimpin yang berkualitas, mampu menggerakkan bawahan untuk mencapai tujuan organisasi dan mampu beradaptasi terhadap perubahan.

\section{KONSEP KEPEMIMPINAN}

Kepemimpinan merupakan kajian yang sangat menarik untuk diteliti, mengingat banyaknya fenomena yang terjadi dalam aspek kepemimpinan, mulai dari karakter, budaya, social dan politik yang mengitarinya. Fenomena kepemimpinan yang terjadi di Indonesia, telah membuktikan tentang bagaimana kepemimpinan memberikan pengaruh yang besar dan kuat terhadap tatanan kehidupan berpolitik dan bernegara.

Kepemimpinan dalam hal ini dimaknai sebagai suatu hubungan saling mempengaruhi, yang terjadi dalam suatu komunitas organisasi, yang diarahkan untuk mencapai tujuan bersama. Di samping itu, jika melihat rumus kepemimpinan yang diajukan oleh Blanchard Kneth and Hersey Paul, (1988), 
maka hubungan antara pemimpin dan yang dipimpin tidak harus selalu berada dalam hubungan yang hirarkis. Hal ini menunjukkan bahwa, kepemimpinan adalah suatu seni dalam kegiatan manajerial atau kemampuan untuk mengkoordinasikan, mempengaruhi, dan menggerakkan individu agar supaya timbul kerja sama secara teratur dalam upaya mencapai tujuan bersama, yang telah ditetapkan sebelumnya.

Dalam Islam, konsep tentang kepemimpinan telah dijelaskan dan diatur dala QS. Al-Baqarah : 30

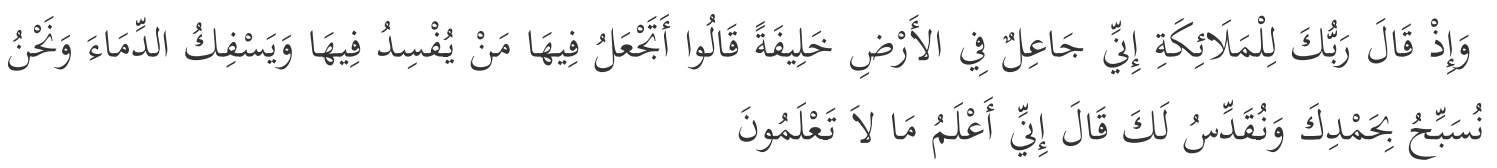

"Ingatlah, ketika Tuhanmu berfirman kepada Mailaikat; "Sesungguhnya Aku hendak menjadikan khalifah di bumi ini". Mereka berkata: "Mengapa Engkau hendak menjadikan khalifah di muka bumi ini yang akan membuat kerusakan padanya dan akan menumpahkan darah, padahal kami senantiasa bertasbih dengan memuji dan mensucikan Engkau?" Allah berfirman: "Sesungguhnya Aku lebih mengetahui tentang apa yang tidak kamu ketahui".

Ayat tersebut menjelaskan bahwa khalifah (pemimpin) adalah pemegang mandat Allah SWT untuk mengemban amanah dan kepemimpinan langit di muka bumi. Oleh karena itu, dalam memimpin suatu ummat atau komunitas masyarakat, diperlukan suatu konsep kepemimpinan yang baik dan berorientasi pada pencapaian tujuan organisasi.

Secara umum, kepemimpinan dipahami sebagai kemampuan atau kesiapan yang dimiliki oleh individu untuk dapat mendorong, mempengaruhi, menuntun, mengajak, menggerakkan, dan kalau perlu memaksa orang lain agar menerima pengaruh tersebut, dan selanjutnya berbuat sesuatu yang dapat membantu tercapainya suatu tujuan bersama yang telah ditetapkan (Freeman, 2010).

Soetopo (2010) menyatakan bahwa kepemimpinan merupakan proses mengarahkan, mempengaruhi, dan mengkoordinasikan segala kegiatan dalam suatu organisasi dan kelompok. Kepemimpinan pada hakikatnya adalah kemampuan seseorang untuk mempengaruhi orang-orang dalam organisasi dengan sistem nilai tertentu dan visi tertentu pula untuk mencapai tujuan.

Kepemimpinan yang sungguh-sungguh tidak diperoleh semata-mata karena pengangkatan, melainkan suatu kehormatan yang diperoleh pemimpin berkat kecakapan-kecakapannya yang telah diperlihatkan dalam mengembangkan usaha-usaha bersama (Purwanto, 1991).

Apabila dihubungkan dengan dunia pendidikan, pengertian kepemimpinan pendidikan adalah kemampuan pemimpin pendidik dalam mempengaruhi para pendidik, tenaga kependidikan, dan siswa dalam 
Al-Tanzim : Jurnal Manajemen Pendidikan Islam E-ISSN: 2549-5720 P-ISSN: 2549-3663

Vol. 03 No. 02 (2019) : 73-84

https:// ejournal.unuja.ac.id/index.php/al-tanzim

mencapai tujuan pendidikan serta mengoptimalkan sumber daya yang dimiliki (Rohmat, 2010). Kepemimpinan dalam pendidikan dimaknai sebagai suatu proses mempengaruhi, mengarahkan, mengajak, mengkoordinasikan, dan membimbing orang yang terlibat langsung maupun tidak langsung dalam kegiatan pendidikan, untuk mencapai tujuan bersama, tanpa adanya paksaan dan tekanan dalam melaksanakan pekerjaannya dengan penuh tanggung jawab.

Fungsi kepemimpinan berhubungan langsung dengan situasi dan kondisi sosial kehidupan kelompok organisasi. Fungsi kepemimpinan yang harus ditunjukkan oleh pemimpin adalah menciptakan visi, misi dan rasa memiliki sebagai sebuah komunitas, membantu mengembangkan komitmen, menginspirasi kepercayaan, membantu menggunakan pengaruh mereka, memfasilitasi, memberi semangat pada yang lain, bertindak sebagai model dan menopang tim (Arifin, 2013).

Kepemimpinan memiliki fungsi untuk menggerakkan bawahan agar mau bertindak dan berbuat sesuatu guna menyukseskan program kerja yang telah ditentukan dan dirumuskan sebelumnya. Dalam hal ini, berhasil tidaknya suatu program dalam organisasi, sebagian besar ditentukan oleh kompetensi dan kemampuan pemimpin dalam melaksanakan fungsi-fungsi pokok kepemimpinannya, baik sebagai leader maupun manager. Pelaksanaan fungsi kepemimpinan sebagai leader lebih menekankan pada interaksi manusiawi (human interactions) untuk mempengaruhi orang lain yang dipimpin, menemukan sesuatu yang baru, mengadakan perubahan dan pembaruan. Sedangkan fungsi manager lebih terfokus pada upaya untuk mengatur dan menggerakkan orang lain (Mutohar, 2013).

Keunikan kajian ini menurut hemat penulis bahwa diskursus kepemimpinan pada umumnya selalu dihadapkan pada dua isu utama yaitu; pertama: sebagian orang menjadi pemimpin sedangkan yang lain menjadi pengikut; kedua: sebagian pemimpin berhasil sedangkan yang lain tidak atau gagal. Pada bagian pertama menghantarkan kita pada pengenalan kualitas karakteristik seseorang yang lebih menonjol dibandingkan orang lain. Sementara pada bagian kedua, secara sederhana merupakan kualitas seseorang dalam kemampuannya untuk menggerakkan seluruh potensi organisasi sehingga mampu untuk survive di tengah perubahan yang ada, bahkan mampu menjadi pemenang dalam setiap kompetisi persaingan. Singkatnya bahwa pemimpin menjadi pembeda dalam eksistensi dalam sebuah lembaga pendidikan termasuk lembaga pendidikan Islam.

Berdasarkan analisis di atas, maka perananan kepemimpinan sangat jelas memiliki andil besar dalam memajukan sebuah lembaga atau keorganisasian. Semua hal itu harus dibarengi dengan peranan kepemimpinan yang mumpuni dalam banyak hal. Selain sebagai seorang pemimpin yang mampu menggerakkan, tetapi juga harus dibarengan dengan inovasi perubahan kebijakan yang akan mampu memberikan perubahan yang positif. 


\section{Kepemimpinan Transformasional; Konsep Kepemimpinan Ideal}

Faktor yang dapat mempengaruhi baik buruknya kinerja seorang karyawan salah satunya adalah cara pemimpin dalam memimpin karyawannya (Setiawan, 2015). Kepemimpinan pada hakikatnya adalah aktivitas atau kegiatan untuk mengarahkan dan mempengaruhi orang lain untuk mencapai suatu tujuan tertentu. Seorang pemimpin harus mampu untuk menciptakan lingkungan kerja yang sesuai dengan para karyawannya, dan juga membina kerja sama antara yang satu dengan yang lainnya, mengarahkan dan mendorong gairah dan motivasi kerja, sehingga dapat menimbulkan dan menghasilkan kinerja yang optimal sesuai dengan kemampuan yang dimilikinya (Septyan, 2017).

Gaya atau model yang ditunjukkan dan ditampilkan oleh pemimpin, dapat dimaknai sebagai suatu sikap, tingkah laku, gerakan, kesanggupan, kecakapan untuk berbuat baik. Gaya kepemimpinan banyak mempengaruhi keberhasilan seorang pemimpin dalam mempengaruhi perilaku bawahannya untuk mencapai suatu tujuan.

Menurut Masaong (2011), gaya kepemimpinan yang ditampilkan oleh seorang pemimpin menunjukkan perilaku konsisten yang diterapkan dalam bekerja dengan dan melalui orang lain guna mencapai tujuan bersama. Gaya kepemimpinan yang ditunjukkan oleh setiap pemimpin merupakan perilaku yang digunakan pada saat orang tersebut mencoba mempengaruhi orang lain. (Munajat, 2013).

Gaya atau model kepemimpinan ini merupakan kepemimpinan yang memiliki visi dan misi ke depan, serta mampu mengidentifikasikan perubahan lingkungan yang ada, dan mampu mentransformasikan perubahan tersebut ke dalam organisasi, mempelopori perubahan dan memberikan motivasi kepada individu-individu untuk kreatif, inovatif, dan berani serta bertanggungjawab untuk memimpin dan mengendalikan organisasi. Terlebih dalam membawa pembaharuan dalam organisasi yang beimplikasi pada peningkatan kinerja pada masing-masing individu (Widayati \& Rahardjo, 2017).

Robbins (2015) menyatakan bahwa, "Kepemimpinan transformasional adalah kepemimpinan yang memberikan inspirasi kepada para pengikutnya untuk melampaui kepentingan pribadi mereka, yang mampu membawa dampak yang luar biasa pada para pengikutnya. Gaya kepemimpinan tranformasional yang diterapkan akan menumbuhkan kepercayaan bagi pengikut, yang merupakan modal bagi tumbuh dan berkembangnya berbagi pengetahuan (Helmi \& Arisudana, 2015).

Yukl (2015) menyatakan bahwa kepemimpinan transformasional dimaknai sebagai suatu cara bagaimana pemimpin memperkuat sikap saling kerjasama (kerja team) dan mempercayai, kemajuan diri secara kolektif, dan pembelajaran tim. Kepemimpinan transformasional meliputi interaksi atau hubungan yang intens antara pemimpin dan karyawannya dalam mengelola 
Al-Tanzim : Jurnal Manajemen Pendidikan Islam E-ISSN: 2549-5720 P-ISSN: 2549-3663

Vol. 03 No. 02 (2019) : 73-84

organisasinya untuk mencapai tujuan yang diinginkan bersama. Hubungan yang baik dengan seluruh individu yang ada pada suatu organisasi, akan dapat mempengaruhi individu yang lain, agar mau melaksanakn perintah dan tugasnya dengan senang hati (Septyan et al., 2017). Melalui kepemimpinan transformasional tersebut, para pengikut merasakan kekaguman, kepercayaan, kesetiaan dan penghormatan terhadap pemimpin. Para pengikut akan termotivasi untuk melakukan dan menunjukkan kinerja yang lebih baik daripada sebelumnya.

Kepemimpinan transformasional membutuhkan dua hal pokok yaitu, pertama, adanya visi yang memungkinkan guru-guru memiliki perasaan terpanggil atau motif intrinsik sebagai pendidik. Motif intrinsik disini yang dimaksud adalah dorongan dari dalam diri seseorang. Apabila seseorang memiliki motif dalam melakukan sebuah pekerjaan, maka pengaruh yang dihasilkan dalam pekerjaannya akan sangat besar. Namun, apabila motifnya tidak kuat, akan membuat seseorang tidak bergairah dalam melakukan suatu pekerjaan. Jika seorang guru memiliki motif intrinsik, maka dalam mendidik muridpun hasilnya akan maksimal, karena guru tahu apa yang sudah menjadi kewajiban dan tanggung jawabnya sebagai seorang guru. Yang kedua adalah budaya sosial atau budaya organisasi, dimana kepala sekolah dan seluruh staf karyawan saling memperhatikan, saling memahami dan menghargai dan mempedulikan secara tulus (Senny et al., 2018).

Kesuksesan pemimpin ditentukan dan dipengaruhi oleh beberapa faktor penting yang dapat menunjang dalam keberhasilannya. Oleh karena itu, suatu tujuan akan tercapai dan berhasil, manakala terjadi keharmonisan, interaksi positif dan saling mendukung antara yang satu yang lainnya. Di samping itu, keberhasilannya juga dipengaruhi oleh latar belakang pemimpin, seperti kedewasaan, karakter, motivasi diri, dan keluwesan dalam melakukan hubungan sosial dengan orang lain.

\section{KEPEMIMPINAN TRANSFORMASIONAL KYAI PADA LEMBAGA PENDIDIKAN ISLAM}

Kyai sebagai pimpinan tertinggi di pondok pesantren, memiliki keunikan tersendiri dalam sistem kepemimpinannya. Istilah Kyai pada konteks keIndonesiaan, tidak hanya bermakna sosok atau individu yang ahli dalam bidang agama, akan tetapi lebih dari itu. Jika ditinjau dari makna antropologis, Kyai adalah individu yang memiliki kelebihan dan mampu dalam segala tataran masalah kehidupan, sekaligus juga sebagai kontrol sosial. Kyai adalah sosok yang penuh dengan aura kharismatik yang sangat tinggi, serta menempati posisi agung (high class) dalam strata social, utamanya bagi umat Islam. Sehingga tidak heran jika segala yang diucapkan oleh Kyai, diyakini oleh masyarakatnya (sami'na wa atho'na). 
Kyai yang dikenal di Indonesia, merujuk kepada figur tertentu yang memiliki kapasitas dan kapabilitas yang memadai dalam ilmu-ilmu keIslaman, karena kemampuannya yang tidak diragukan lagi. Dalam struktur masyarakat Indonesia, figur Kyai memperoleh pengakuan akan posisi pentingnya di masyarakat (Yaqin, 2016).

Sebagai pimpinan di pondok pesantren, Kyai merupakan sosok penting dan elemen sentral dalam kehidupan di pondok pesantren. Posisi ini tidak saja karena peran Kyai sebagai penyangga utama bagi kelangsungan sistem pendidikan di pondok pesantren, akan tetapi disebabkan karena sosok Kyai merupakan cerminan dari nilai kehidupan yang hidup di lingkungan komunitas santri.

Dalam diri Kyai terdapat beberapa kemampuan, diantaranya ia sebagai perancang (arsitektur), pendiri dan pengembang (developer), dan sekaligus sebagai seorang pemimpin dan pengelola (leader dan manager) pesantren (Mardiyah, 2013). Kyai sebagai pemimpin di pondok pesantren apabila ditinjau dari tugas dan fungsinya memiliki fenomena yang unik. Dikatakan unik, karena Kyai sebagai pemimpin tertinggi sebuah lembaga pendidikan Islam tidak sekedar bertugas menyusun dan mendesain kurikulum, membuat tata tertib pelaksanaan program pendidikan, melakukan penilaian dan pengukuran, melainkan bertugas pula sebagai pembina dan pendidik umat di sekitarnya, serta menjadi pemimpin masyarakat (Arifin, 1993).

Adanya pengaruh yang cukup besar ini mengindikasikan bahwa sosok pemimpin memiliki basis masa yang sangat banyak. Salah satu contoh adalah ; Kyai sebagai tokoh agama yang banyak memberikan konstribusi dalam mengembangkan dan membangun masyarakat. Dalam kehidupan sosial, Kyai menjadi figure utama yang begitu disegani dan dijadikan sebagai tokoh sentral.

Kepemimpinan kiai dalam pesantren sangat unik dari segi kekukuhannya pada ciri-ciri pra modern. Semisal pola hubungan antara pemimpin dan pengikut yang lebih berdasar pada sistem kepercayaan dari pada hubungan patron-client pada masyarakat umumnya. Santri menerima kepemimpinan Kyai karena kepercayaan mereka pada konsep barokah yang didasarkan pada doktrin emanasi kaum sufi (Mardiyah, 2013).

Dalam memimpin pesantrennya, tentunya Kyai dihadapkan pada perubahan sosial, kultur, ekonomi dan politik, sehingga memberikan dampak yang cukup besar bagi keberlangsungan pendidikan di pesantren. Oleh karena itu, untuk menghadapi perubahan-perubahan lingkungan internal dan eksternal yang sulit diramalkan di pondok pesantren, maka diperlukan pemimpin masa depan yang visioner dan tranformatif.

Kepemimpinan transformatif dalam hal ini dipahami sebagai suatu aktivitas di mana pemimpin yang memberikan perhatian individual dengan memberikan tugas yang sesuai dengan kompetensi bawahannya, serta mampu menerapkan stimulasi intelektual kepada bawahannya (Septyan et al., 2017). Dalam memerankan kepemimpinan transformatif, Kyai sebagai pimpinan 
Al-Tanzim : Jurnal Manajemen Pendidikan Islam E-ISSN: 2549-5720 P-ISSN: 2549-3663

Vol. 03 No. 02 (2019) : 73-84

https:// ejournal.unuja.ac.id/index.php/al-tanzim

pesantren memberikan stimulasi kepada para pengurus dan santri untuk menjalankan perannya sebaik mungkin, baik sebagai orang yang bertanggung jawab dalam memanage pesantren dan santri, maupun dalam menjalankan tugas sebagai santri yang harus belajar dengan sungguh-sungguh.

Kyai sebagai pemimpin yang transformatif dalam mengelola pesantrennya, setidaknya melaksanakan empat dimensi kepemimpinan tranformasional, sebagaimana yang telah disampaikan oleh Yukl (2015), yaitu ; Pertama, karismatik yang digambarkan sebagai perilaku pemimpin yang membuat para pengikutnya mengagumi, menghormati, dan sekaligus mempercayainya. Dalam hal ini, Kyai adalah sosok yang dipandang memiliki kelebihan dan dianggap superior dalam bidang agama oleh masyarakat sekitarnya, sehingga beliau diangkat sebagai tokoh yang mampu untuk memberikan petunjuk dan siraman rohani kepada masyarakat di sekitarnya.

Melalui kharisma yang dimiliki dan melekat pada dirinya, Kyai dijadikan sebagai pemimpin atau imam dalam bidang 'ubûdiyyah (keagamaan) dan sering diminta pendapat dan kehadirannya untuk menyelesaikan problematika yang dihadapi dan menimpa masyarakat. Rutinitas ini semakin memperkuat posisi dan peran Kyai dalam kehidupan masyarakat, sebab kehadirannya diyakini akan membawa berkah dan ketenangan dalam komunitasnya. Misalnya, banyak Kyai yang diminta untuk mengobati orang sakit, memberikan nasehat spiritual, diminta do'a untuk melariskan barang dagangan, memberikan ceramah agama, dan lain sebagainya. Kharisma Kyai sangat diakui oleh masyarakat, karena dia dipandang memiliki kelebihan, kemantapan moral dan kecerdasan spiritual yang melahirkan model kepribadian (Susanto, 2017), sehingga mampu menjadi magnet bagi para pengikutnya.

Kedua, inspirational motivation yang digambarkan sebagai pemimpin yang mampu mengartikulasikan pengharapan yang jelas dari seluruh pengikutnya, baik untuk mendapatkan ketenangan lahiriah maupun ketenagan batiniah. Dalam aspek ini pula, Kyai mampu menunjukkan komitmennya terhadap apa yang telah disampaikan kepada seluruh pengikutnya dan mampu menggugah spirit pengikutnya melalui penumbuhan optimism dan antusiasme.

Ketiga, intellectual stimulation digambarkan sebagai perilaku pemimpin dalam menumbuh kembangkan ide-ide baru dari bawahannya, memberikan solusi yang inovatif dan kreatif terhadap permasalahan-permasalahan yang ada dan dihadapi oleh bawahannya. Keempat, individualized consideration, yang dimana Kyai diposisikan dengan seorang pemimpin yang mau mendengarkan aspirasi dan masukan-masukan orang lain.

Kepemimpinan transformasional yang ditampilkan dan tunjukkan oleh Kyai, akan mampu mengajak para bawahannya untuk melakukan tugas-tugas mereka melebihi dari kepentingan mereka sendiri, demi kepentingan pencapaian tujuan organisasi yang lebih besar (Podungge, 2018). 
Dengan penerapan gaya kepemimpinan transformasional, maka anggota akan melakukan tugasnya dengan maksimal dikarenakan pemberian tugas dari pemimpin bukanlah suatu beban yang berat. Hal tersebut disebabkan pemimpin dapat mempengaruhi anggotanya sehingga ketika diberikan tugas, anggota akan menerima dengan senang hati (Senny et al., 2018). Dengan diterapkan kepemimpinan transformasional maka bawahan akan merasa dipercaya, dihargai dan bawahan akan lebih menghargai pimpinanya

\section{KESIMPULAN}

Dalam perjalanannya, Kyai sebagai pimpinan tertinggi di pondok pesantren, memiliki peran yang cukup besar dalam membentuk dan membangun karakter peserta didik yang baik dan unggul, sehingga mampu memberikan konstribusi yang besar bagi kemajuan Indonesia. Kyai yang telah mampu membawa tatanan sosial masyarakat Indonesia ke ranah yang lebih tinggi, membuktikan bahwa sosok Kyai memiliki dimensi lain yang tidak dimiliki oleh kepemimpinan formil pada umumnya. Karismatik trend, juga patrenialis style tentunya mampu menjawab persoalan kepemimpinan seorang Kyai.

Berangkat dari hal tersebut, tentu harapan kepemimpinan yang memiliki visi dan misi untuk memajukan lembaga pendidikan Islam benar-benar diharapkan konstribusinya, khususnya dalam menjaga nilai-nilai religious yang berkembang di masyarakat, melalui konsep amar ma'ruf wa nahi munkar. Selain itu, seorang pemimpin lembaga pendidikan Islam juga haru mampu berinovasi dan melakukan tranformasi kelembagaan agar supaya dapat eksis dan unggul di tengah persaingan antara lembaga pendidikan yang ada. 
Al-Tanzim : Jurnal Manajemen Pendidikan Islam E-ISSN: 2549-5720 P-ISSN: 2549-3663

Vol. 03 No. 02 (2019) : 73-84 https:// ejournal.unija.ac.id/index.php/al-tanzim

\section{DAFTAR PUSTAKA}

Abd. Kadim Masaong, dan A. A. T. (2011). Kepemimpinan Multi Intelligens (Sinergi Kecerdasan Intelektual, Emosional dan Spiritual untuk Meraih Kesuksesan Gemilang. Bandung: Alfabeta.

Afandi, R. (2013). Kepemimpinan dalam Pendidikan Islam. Insania, 18(1), 95116.

Arifin, V. R. dan A. (2013). Islamic Leadership; Membangun Super Leadership Melalui Kecerdassan Spiritual. Jakarta: Bumi Aksara.

Blanchard Kneth and Hersey Paul. (1988). Management of Organization Behavior. Singapore: Prentice Hall. Inc.

Freeman, G. T. (2010). Spirituality and Servant Leadership: A Conceptual Model and Research Proposal. Emerging Leadership Journeys, 4(1), 120140. from http://www.regent.edu/acad/global/publications/elj/vol4iss1/Freem an_V4I1_pp120-140.pdf

Grisham, T. (2006). Cross-cultural leadership in construction. Proceedings of the International Conference on Construction Culture, Innovation, and Management, Dubai, UAE, 26-29.

Guthrie, K. L., \& Ph, D. (2010). Creating Meaningful Environments for Leadership Education. Journal of Leadership Education, 9(2), 50-57.

Helmi, A. F., \& Arisudana, I. (2015). Kepemimpinan Transformasional, Kepercayaan dan Berbagi Pengetahuan dalam Organisasi. Jurnal Psikologi (Yogyakarta), 36(2), 95-105. https://doi.org/10.22146/jpsi.7888

Munajat, N. (2013). Administrasi Pendidikan. Yogyakarta: Fakultas Ilmu Tarbiyah dan Keguruan UIN Sunan Kalijaga.

Murtiningsih. (2015). Pengaruh Gaya Kepemimpinan Transformasional Pada Kinerja Perawat Rumah Sakit Islam Siti Aisyah Madiun. DAYA SAING Jurnal Ekonomi Manajemen Sumber Daya, 17(2), 54-66.

Mutohar, P. M. (2013). Manajemen Mutu Madrasah: Strategi Peningkatan Mutu dan Daya Saing Lembaga Pendidikan Islam. Yogyakarta: Ar-Ruzz Media.

Podungge, A. W. (2018). Pengaruh Kepemimpinan Transformasional terhadap Peningkatan Kualitas Kinerja Pegawai di Dinas Pendidikan Kabupaten Bone Bolango. Gorontalo Journal of Public Administration Studies, 1(1), 56. https:/ / doi.org/10.32662/gjpads.v1i1.179

Purwanto, N. (1991). Administrasi Pendidikan. Jakarta: Mutiara Sumber Widya.

Rohmat. (2010). Kepemimpinan Pendiidkan; Konsep dan Aplikasi. Purwokerto: STAIN Press.

Senny, M. H., Wijayaningsih, L., \& Kurniawan, M. (2018). Penerapan Gaya Kepemimpinan Transformasional Dalam Manajemen PAUD di Kecamatan Sidorejo Salatiga. Scholaria: Jurnal Pendidikan Dan Kebudayaan, 8(2), 197-209. https://doi.org/10.24246/j.js.2018.v8.i2.p197-209 
Septyan, F. B., Musadieq, M. Al, \& Mochammad Djudi Mukzam. (2017). Pengaruh Gaya Kepemimpinan Transformasional Terhadap Motivasi Dan Kinerja (Studi Pada Karyawan Cv. Jade Indopratama Malang). Jurnal Administrasi Bisnis (JAB), 53(1), 81-88. Retrieved from http://administrasibisnis.studentjournal.ub.ac.id/index.php/jab/article / view/2185

Setiawan, E. Y. (2015). Pengaruh Gaya Kepemimpinan Transformasional Dan Transaksional Terhadap Kinerja Karyawan PT. ISS Indonesia di Rumah Sakit National Surabaya. eJ - UR N a L I L M U M a N a J E M E N M A G I $S$ T R A, 1(1), 31-41.

Soetopo, H. (2010). Perilaku Organisasi; Teori dan Praktik di Bidang Pendidikan. Bandung: PT Remaja Rosdakarya.

Stephen P. Robbins, dan T. A. J. (2015). Perilaku Organisasi. Jakarta: Salemba Empat.

Susanto, E. (2017). Kepemimpinan Kharismatik Kyai dalam Perspketif Masyarakat Madura. Karsa, 11(1), 30-40.

Suyatminah, S. (2013). Peran Kepemimpinan Transformasional dan Kedisiplinan Kerja Terhadap Kinerja Guru TK PNS se-Kecamatan Bantul. PSIKOPEDAGOGIA Jurnal Bimbingan Dan Konseling, 2(2), 87. https://doi.org/10.12928/psikopedagogia.v2i2.2575

Syahrul. (2015). Kepemimpinan dan Inovasi lembaga Pendidikan (Pengalaman Pondok Gontor VII Putera Sulawesi Tenggara). Jurnal Al-Ta'dib, 8(1), 82100.

Syam, A. R. (2017). Konsep Kepemimpinan Bermutu Dalam Pendidikan Islam. Al-Ta'dib, 12(2), 49-69.

Widayati, C., \& Rahardjo, T. H. (2017). Widayati, Rahardjo dam Febriyanti: Pengaruh Kepemimpinan Transformasional... Jurnal Ekonomi, 22(3), 466485.

Yaqin, N. (2016). Manajemen Lembaga Pendidikan Islam. Studi Islam, 3(2), 93105.

Yukl, G. (2015). Kepemimpinan Dalam Organisasi. Jakarta: Indeks. 